\title{
ACRODERMATITIS CONTINUA OF HALLOPEAU YANG MEMBERI RESPONS BAIK TERHADAP TERAPI KOMBINASI SALEP KLOBETASOL PROPIONAT 0,05\% DAN DAPSON
}

\author{
Yuli Megasasi, Herwinda Brahmanti, Yasmina Diah Kumala, Galih Manggala \\ Bagian/SMF Ilmu Kesehatan Kulit dan Kelamin \\ FK Universitas Brawijaya / Rumah Sakit Umum dr. Saiful Anwar Malang
}

\begin{abstract}
ABSTRAK
Acrodermatitis continua of Hallopeau (ACH) merupakan kasus jarang, yang ditandai dengan erupsi pustular steril yang mengenai ujung jari tangan dan kaki. Pengobatan ACH sulit karena kondisinya yang rekalsitran. Berbagai terapi menggunakan obat topikal atau sistemik, secara tunggal atau kombinasi telah dicoba dengan hasil yang bervariasi.

Seorang anak perempuan 10 tahun dengan ACH kuku keempat dan kelima jari tangan kanan dan kuku ketiga jari tangan kiri sejak 5 tahun sebelum berobat. Pengobatan awal dengan salep klobetasol propionat 0,05\% saja gagal memperbaiki lesinya. Kombinasi dengan dapson $50 \mathrm{mg} / \mathrm{hari}$ menghasilkan perbaikan lesi akral dalam waktu empat minggu, namun terdapat efek samping anemia.

Steroid topikal superpoten memiliki mekanisme kerja sebagai anti-inflamasi, anti-proliferasi, imunosupresif, dan vasokonstriksi, terutama jika digunakan secara oklusif, berguna untuk menghentikan pustulasi. Dapson menghambat kemotaksis neutrofil manusia melalui sistem transduksi sinyal protein G dan mengganggu migrasi kemotaktik neutrofil melalui supresi fungsi adhesi ke epidermis yang diperantarai oleh integrin. Hal tersebut menyebabkan supresi perekrutan neutrofil serta kurangnya influks neutrofil ke dalam dermis. Kombinasi salep klobetasol propionat 0,05\% yang dioklusi dan dapson dianjurkan untuk ACH
\end{abstract}

Kata kunci: Acrodermatitis continua of Hallopeau, klobetasol propionat, dapson

\section{CONTINUA ACRODERMATITIS OF HALLOPEAU WHICH GIVES GOOD RESPONSE TO COMBINATION THERAPY SALEP KLOBETASOL PROPIONAT 0,05\% AND DAPSON}

\begin{abstract}
Acrodermatitis continua of Hallopeau (ACH) is a rare, sterile, pustular eruption, chronic, inflammatory, relapsing dermatosis of the fingers and toes. Treatment of $\mathrm{ACH}$ is difficult because the condition is invariably recalcitrant to the available therapies. Various therapies have been attempted with both topical or systemic drugs, alone or in combination with varying results.

A 10-year old girl suffered from pustular eruptions of ACH on right fourth and fifth of fingernails and left third of fingernail for about 5 years. Initial treatment with $0.05 \%$ clobetasol propionate ointment alone failed to improve the acral lesions. The combination of clobetasol $0.05 \%$ twice daily with dapsone was given at a dose of $50 \mathrm{mg} /$ day, resulted cleared the acral lesions within four weeks of therapy,but there was dapsone-related side effects were noted that was anemia.

Potent or superpotent topical steroids have potential action as anti-inflammatory, anti-proliferative, immunosuppressive, and vasoconstrictive, preferentially under occlusion, are useful in blocking pustulation. Dapsone inhibits human neutrophilic chemotaxis through $G$ protein signal transduction system and interferes with neutrophil chemotactic migration through suppression of integrin-mediated adhesion function to the epidermis. This suppresses neutrophil recruitment and accounts for the lack of influx of neutrophils into the dermis. Combination of $0.05 \%$ clobetasol propionate ointment under occlusion and dapsone is recommended for ACH
\end{abstract}

Keywords: Acrodermatitis continua of Hallopeau,clobetasol propionate, dapsone

Korespondensi:

Jl. Jaksa Agung Suprapto No.2 Malang.

Telp : 0341- 340991

Email : yulimegasasi@ymail.com 


\section{PENDAHULUAN}

Istilah acrodermatitis continua of Hallopeau (ACH) awalnya dideskripsikan oleh Hallopeau pada 1890 sebagai erupsi pustular steril pada distal falangs. Penyakit ini ditandai oleh awitan akut eritema yang sangat nyeri dan pembentukan pus steril di bagian distal jari diikuti dengan sisik dan krusta. Pus sering melibatkan lempeng kuku dan daerah periungual yang menyebabkan distrofi kuku, dan perjalanan penyakit yang berkepanjangan dapat menyebabkan anonikia total. Acrodermatitis sering terjadi pada satu jari namun dapat melibatkan semua jari dan terkadang jari kaki. Penyakit ini juga dapat menyebar ke proksimal melibatkan keseluruhan permukaan tangan atau kaki dan pada kasus yang jarang melibatkan seluruh tubuh. ${ }^{1,2,3}$

Ciri histopatologis utama ditandai oleh pus spongioformis dengan agregat neutrofil di antara keratinosit yang terdegenerasi. ACA dianggap banyak ahli sebagai varian psoriasis pustular karena ciri histologis yang serupa. Lesi yang sudah lama terbentuk atau kronik relaps menunjukkan atrofi berat papila dermis dan penipisan epidermis. Akantosis sedang, eksositosis limfositik dan neutrofilik serta spongiosis menunjukkan perubahan patologis mencolok yang dapat diamati pada spesimen yang diambil dari matriks kuku. ${ }^{1,4}$

Tidak terdapat obat spesifik untuk psoriasis pustular yang mampu menginduksi remisi yang bertahan lama. Steroid topikal poten atau superpoten, biasanya secara oklusif, berguna dalam mencegah pustulasi. Terapi kombinasi dengan obat sistemik berhasil pada beberapa pasien. Pada pasien dengan penyakit yang persisten, dap- son dapat dicoba. ${ }^{2}$ Dapson (4-4' diaminodiphenyl sulfone), yang dianggap sebagai agen anti-inflamasi kuat dengan target kerja neutrofil, telah sukses digunakan pada berbagai dermatosis yang terkait dengan infiltrasi neutrofil. Obat ini juga dilaporkan dapat memutus rantai perkembangan ACH refraktorik. ${ }^{1}$ Dilaporkan satu kasus ACH pada anak perempuan berusia 10 tahun yang diterapi dengan kombinasi salep klobetasol propionat 0,05\% dan dapson.

\section{KASUS}

Seorang anak perempuan berusia 10 tahun, suku Jawa, dibawa berobat oleh orang tuanya ke poliklinik Ilmu Kesehatan Kulit dan Kelamin Rumah Sakit dr. Saiful Anwar Malang dengan keluhan utama hilangnya kuku jari tangan. Hilangnya kuku jari tangan keempat dan kelima kanan dan jari ketiga kiri terjadi sejak 5 bulan yang lalu. Awalnya, muncul kemerahan dan bernanah disertai nyeri dan gatal pada ujung jari yang terkena. Selanjutnya kuku menjadi rusak dan terlepas. Setelah kuku terlepas, nanah masih muncul dan membentuk kerak cokelat tebal. Keluhan tersebut terjadi berulang selama 5 tahun. Ketika sembuh, kuku tersebut kembali tumbuh lagi. Tidak ada keluhan pada kuku kaki. Tidak ditemukan ruam pada kulit maupun telapak tangan dan kaki. Tidak terdapat riwayat penyakit yang sama dalam keluarganya. Tidak terdapat riwayat pembengkakan dan nyeri pada sendi.

Pemeriksaan dermatologis menunjukkan pustul dan krusta tebal kecoklatan dengan eritema di kulit sekitarnya pada kuku ke-empat dan ke-lima jari tangan kanan dan

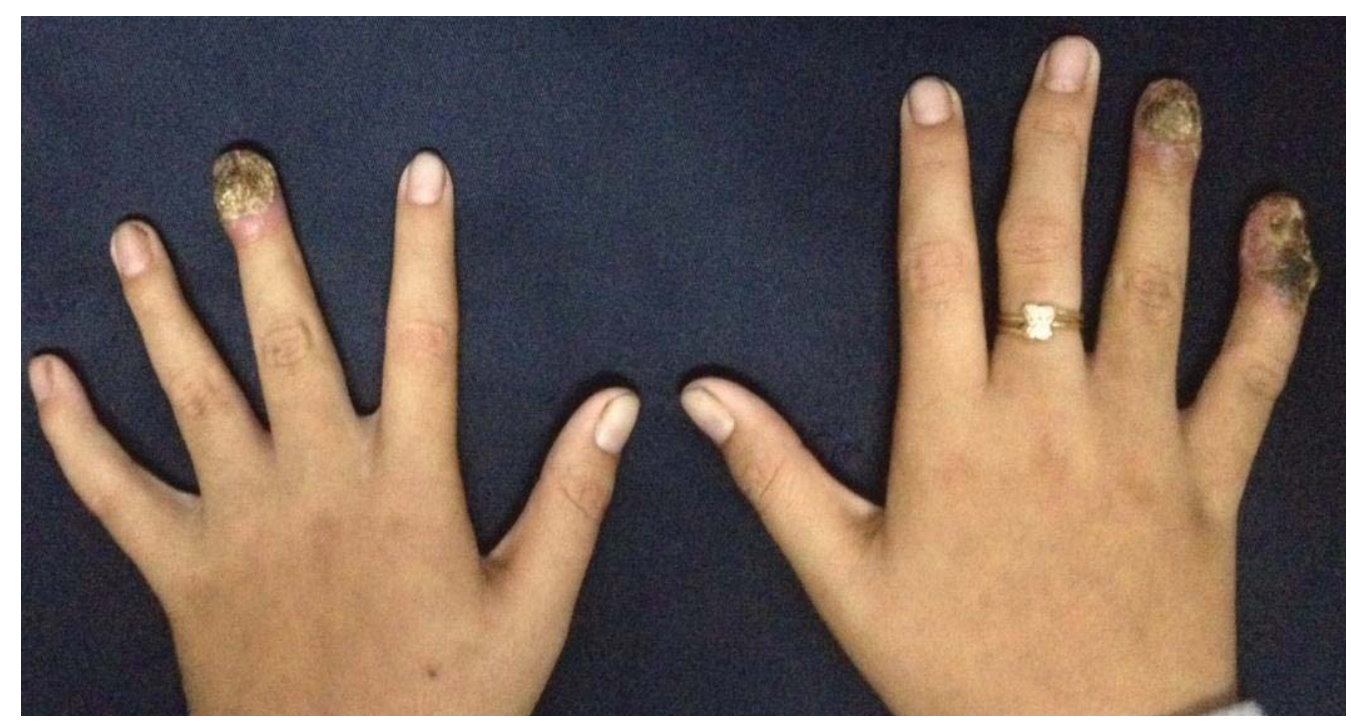

Gambar 1. Pustul dan krusta tebal kecoklatan dengan eritema di kulit sekitarnya pada kuku jari ke-empat dan ke-lima tangan kanan dan kuku jari ke-tiga tangan kiri 
Hasil pewarnaan Gram maupun kultur pada pustul adalah steril. Pemeriksaan biopsi punch pada kulit yang eritematosa berdekatan dengan kuku kelima jari tangan kanan menunjukkan adanya ortokeratosis berupa anya- man keranjang spongiosis ringan tanpa infiltrat sel neutrofil, akantosis ringan pada epidermis dan ekstasi vaskular pada papila dermis serta infiltrasi sel radang limfosit di perivaskular dermis superfisial (gambar 2).
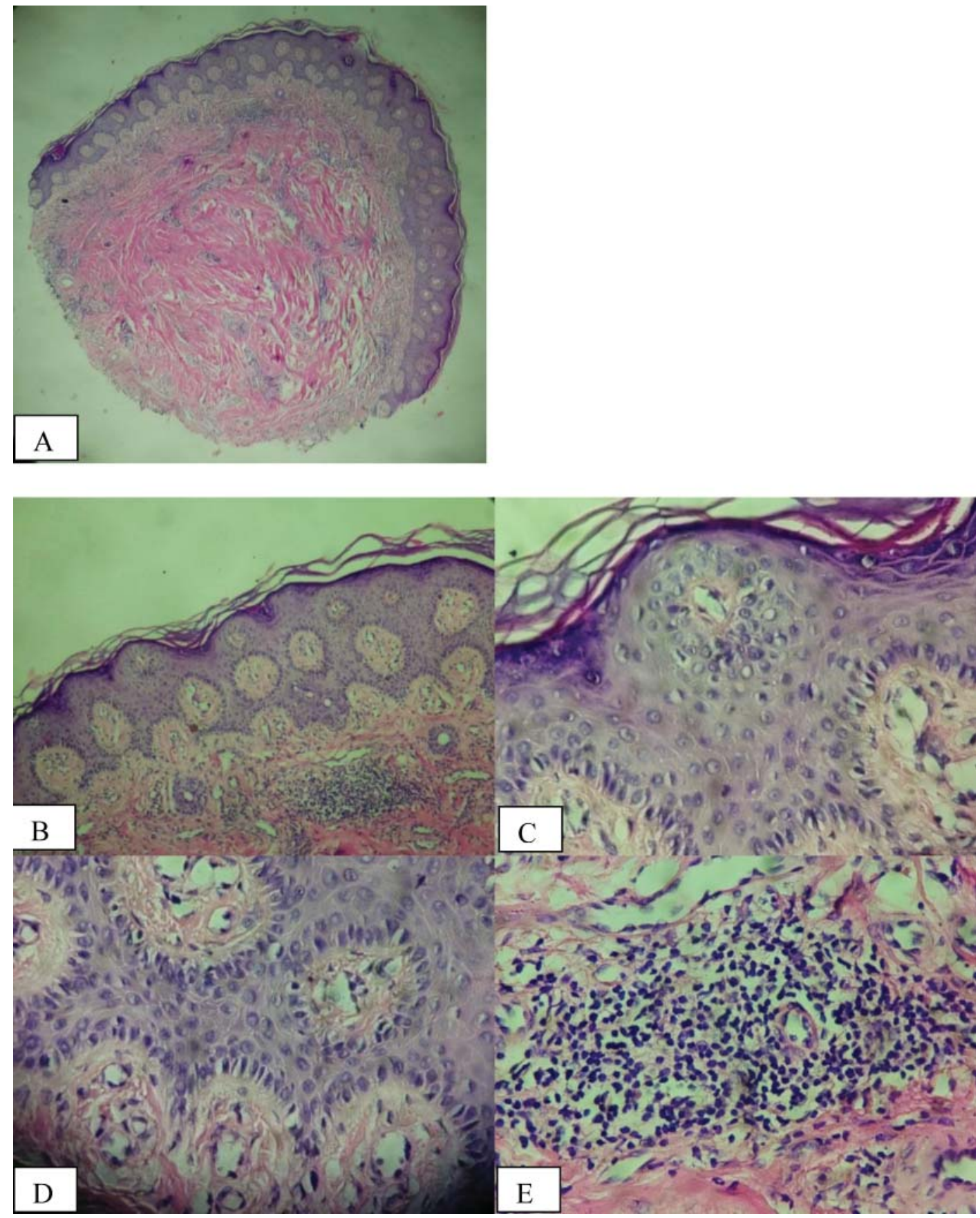

Gambar 1. Histopatologi ACH dari biopsi punch pada kulit eritema diambil dari dekat kuku jari ke-5 tangan kanan (HE, 40x) (A). Terdapat ortokeratosis berupa "anyaman keranjang" (HE, 100x) (B), spongiosis ringan tanpa infiltrat sel neutrofil dan akantosis ringan di epidermis (C), dan ektasi vaskular pada dermis papilla (D), infiltrasi sel radang limfosit perivaskular di dermis superfisial (E) (HE, 400x) 
Pemeriksaan radiologis jari tangan kanan dan kiri menunjukkan osteoporosis dan tidak ditemukan osteoli- tik (gambar 3). Pemeriksaan darah lengkap dan kimia darah dalam batas normal.
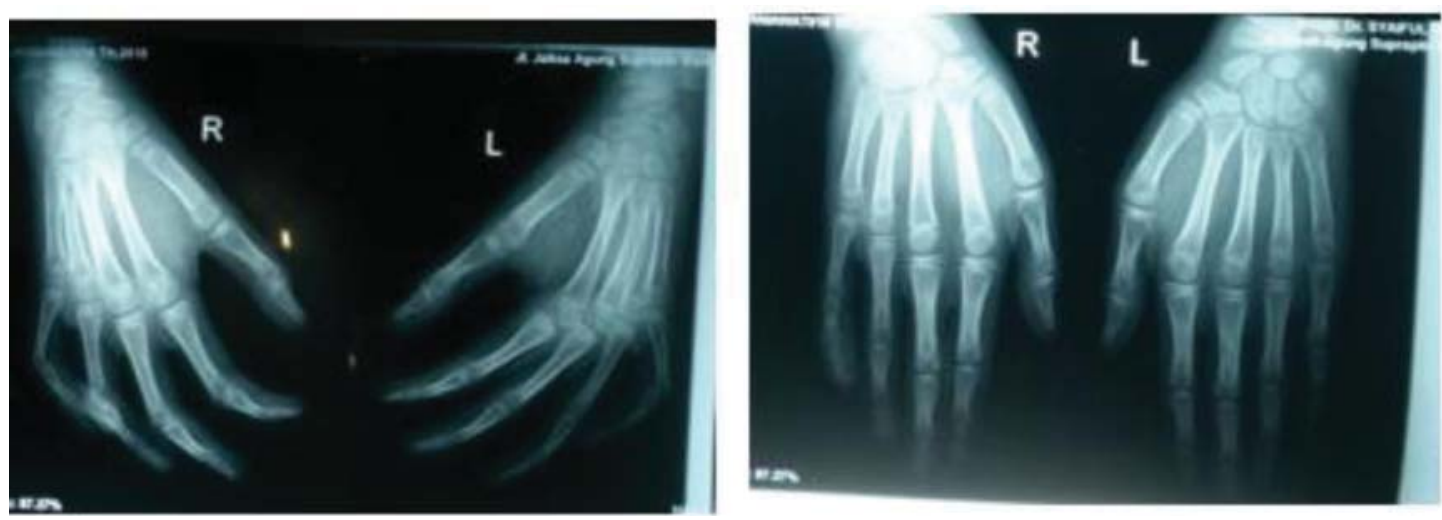

Gambar 3. Gambaran radiologis jari tangan kanan dan kiri

Berdasarkan anamnesis, pemeriksaan dermatologis, dan pemeriksaan mikroskopis, pasien didiagnosis sebagai acrodermatitis continua of Hallopeau. Pasien diterapi dengan salep klobetasol propionat 0,05\% yang dioklusi dua kali sehari dan kompres larutan salin nor- mal pada krusta. Pemantauan ulang setelah 1 bulan, tidak terdapat perbaikan lesi. Pustulasi masih terbentuk dan diikuti pembentukan krusta cokelat tebal. Kulit di sekitar kuku masih eritematosa (gambar 4).

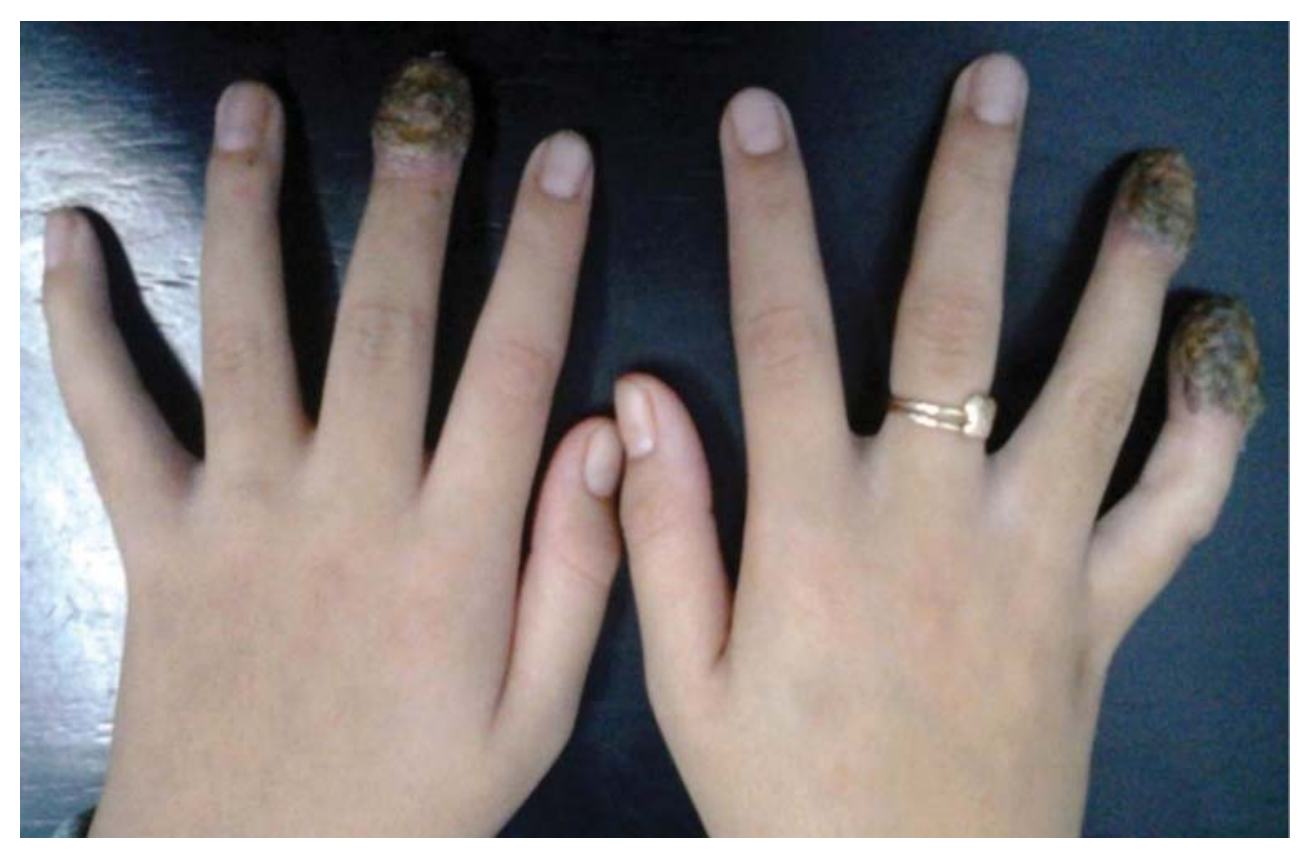

Gambar 4. Pemantauan ulang 1 bulan setelah pengobatan salep klobetasol propionat 0,05\% yang dioklusi dua kali sehari.

Setelah dilakukan pemeriksaan lengkap dan kadar hemoglobin serta fungsi hati hasilnya normal, dapson 50 $\mathrm{mg} /$ hari diberikan bersama dengan salep klobetasol propionat $0,05 \%$ yang dioklusi dua kali sehari dan kompres larutan salin normal pada krusta.

Satu bulan kemudian, terdapat perbaikan lesi dan tidak terbentuk pustulasi baru. Krusta secara bertahap menipis, eritematosa pada kulit juga berkurang. Terdapat anonikia, kulit tampak atrofi, dan terjadi penipisan bagian distal falang (gambar 5). Pada evaluasi pemeriksaan laboratorium, kadar hemoglobin menurun sehingga dapson dihentikan. 


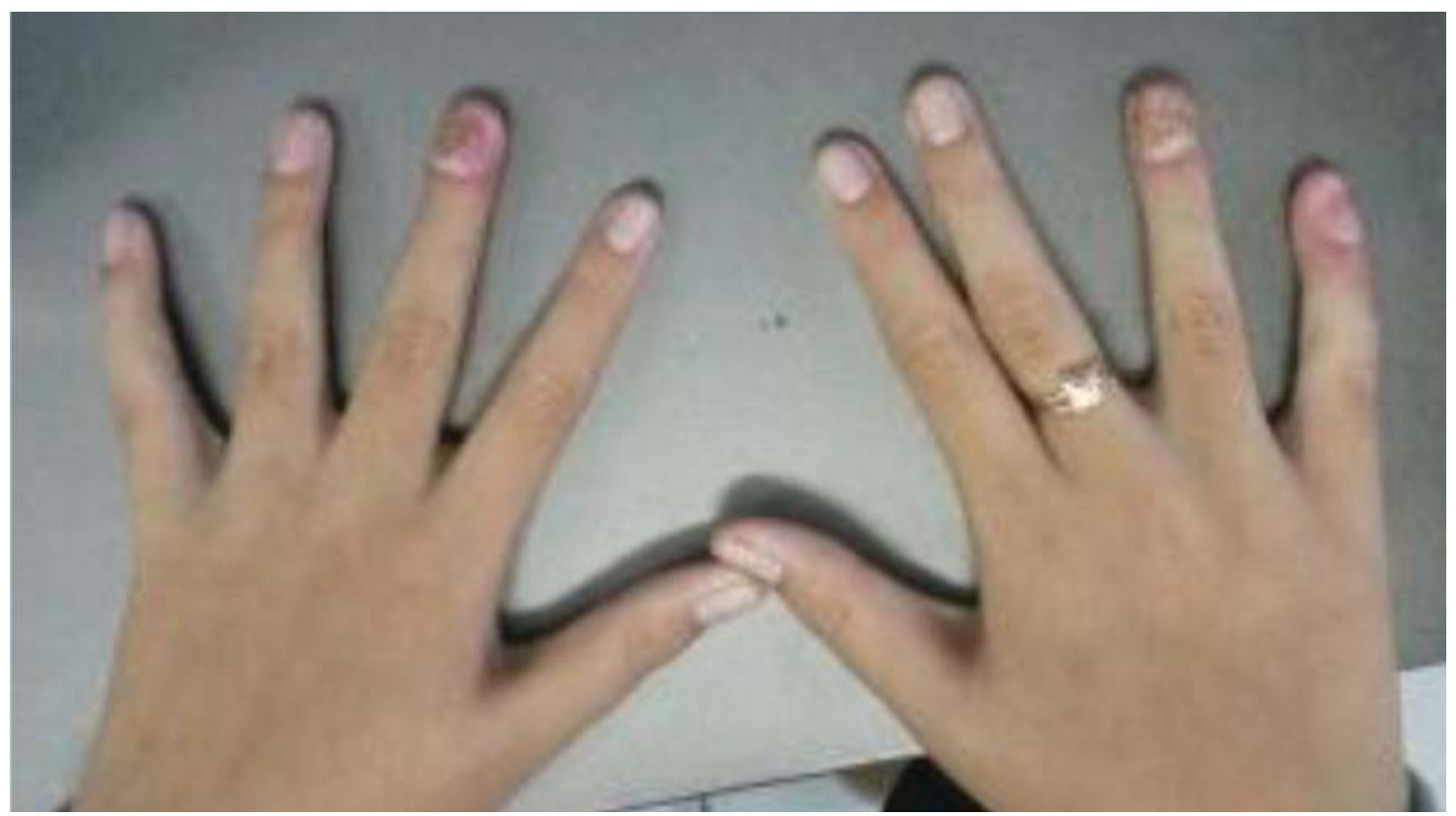

Gambar 5. Pemantauan ulang setelah 1 bulan pengobatan dengan kombinasi dapson $50 \mathrm{mg} /$ hari dan salep klobetasol propionat 0,05\% yang dioklusi dua kali sehari.

\section{DISKUSI}

Acrodermatitis continua of Hallopeau (ACH) merupakan dermatosis pada jari tangan dan kaki yang jarang, ditandai oleh erupsi pustular steril, kronis, inflamatorik, dan sering relaps. Acrodermatitis continua of Hallopeau saat ini diklasifikasikan sebagai satu bentuk psoriasis pustular $^{2,4}$ terutama karena kasus ACH yang berkembang menjadi psoriasis pustular generalisata (GPP) telah dilaporkan. ${ }^{5}$

Tidak terdapat data mengenai prevalensi atau insidens ACH. ${ }^{2}$ Penyakit ini terjadi paling umum pada wanita paruh baya dan sering dimulai setelah trauma lokal atau infeksi pada satu jari. ${ }^{4,6}$ Pembentukan pus dapat serupa seperti yang terjadi pada pustulosis palmoplantar (PPP), namun karena jarangnya penyakit ini, maka hal tersebut belum diteliti. ${ }^{2}$ Pada jurnal ini dilaporkan kasus jarang ACH yang ditemukan pada anak perempuan berusia 10 tahun. Tidak terdapat riwayat trauma atau infeksi sebelum lesi muncul. Tidak ditemukan ruam pada kulit baik di telapak tangan dan telapak kaki. Tidak terdapat riwayat penyakit serupa di keluarganya. Tidak terdapat riwayat bengkak dan nyeri di sendinya.

ACH biasanya dimulai dari ujung satu atau dua jari dan jarang dimulai dari jari kaki. Karakteristik klinis lesi bervariasi berdasarkan tahap evolusinya. Episode akut secara klinis ditandai dengan pustul kecil, yang saat pecah, meninggalkan daerah eritematosa berkilap di tempat pustul baru terbentuk. Lesi tersebut cenderung berkumpul, membentuk kumpulan pus polisiklik. Seiring dengan perluasan penyakit ke proksimal, daerah yang terkena menunjukkan eritema berkilap atau permukaan keratotik dengan krusta dan fisura dengan pustul yang baru terbentuk dibawahnya. Pustulasi dari dasar kuku dan matriks kuku hampir selalu terjadi dan seringkali menyebabkan hilangnya lempeng kuku atau onikodistrofi berat. Pada kasus kronis dan lama, destruksi menyeluruh dari matriks kuku dapat terjadi dan akhirnya dapat menyebabkan anonikia. Kulit menjadi sangat atrofik, dan penipisan bagian distal falangs terjadi, selain itu dapat terjadi osteitis falangs yang menyebabkan osteolisis dan keterlibatan sendi interfalangeal. . $^{2,4,7,8}$

Perkembangan klinis yang telah dijelaskan di atas sejalan dengan yang ditemukan pada pasien ini. Pada kasus ini, sekumpulan pustul terbentuk pada daerah eritema di bagian akral dari jari yang terkena. Pustula cenderung berkumpul dan membentuk kumpulan pus polisiklik. Jaringan nekrosis yang mengering menghasilkan krusta berwarna coklat, tebal, yang ketika dikerok menunjukkan formasi pustul baru di bawahnya. Kadang, lesi terasa nyeri dan gatal. Atrofi kulit tampak seiring dengan perkembangan penyakit. Pustulasi yang terus menerus pada dasar kuku dan matriks kuku menyebabkan destruksi lempeng kuku, onikodistrofi berat dan onikolisis.

Selain tanda klinis yang diuraikan di atas, diagnosis ACH harus ditegakkan melalui pemeriksaan histopatologis biopsi lesi kulit, pewarnaan Gram dan pembuatan perparat potasium hidroksida $(\mathrm{KOH})$ dari pustul. Kultur in vitro dari bahan tersebut wajib dilakukan. Hasil biakan dapat steril atau ditumbuhi oleh saprofit. ${ }^{4}$ Pada kasus ini, diagnosis ditegakkan berdasarkan anamnesis, 
pemeriksaan fisik, pewarnaan Gram dan kultur pus. Pada anamnesis didapatkan bahwa perjalanan penyakit pasien ini sesuai dengan evolusi lesi ACH. Pemeriksaan dermatologis menunjukkan pustul dan krusta kecoklatan yang tebal dengan eritema pada sekitar kulit di kuku jari keempat dan lima tangan kanan dan kuku jari ke-tiga tangan kiri (gambar 1) dan hasil pewarnaan Gram serta kultur dari pus adalah steril.

Secara histopatologis, ACH memiliki ciri psoriasis pustular, yaitu pustul subkorneal neutrofilik. Pustul spongiform, suatu agregat neutrofil di dalam celah jaringan spongiosis, terbentuk dari sel epidermal yang terdegenerasi dan mengalami penipisan di lapisan atas dari epidermis. Perubahan dermal meliputi infiltrat limfohistiositik sedang dan edema fokal. Lesi yang sudah berlangsung lama atau lesi relaps kronis menunjukkan atrofi berat papila dermis dan penipisan epidermis. Akantosis sedang, eksositosis limfositik dan neutrofilik, serta spongiosis menunjukkan perubahan patologis yang prominen didapat dari spesimen yang diambil dari matriks kuku. ${ }^{4,7,9}$ Pada kasus ini, biopsi plong dari kulit eritematosa di dekat dasar kuku pada jari kelima tangan kanan menunjukkan ortokeratosis berupa 'anyaman keranjang', spongiosis ringan tanpa infiltrat sel neutrofil dan akantosis ringan pada epidermis dan ektasi vaskular pada papila dermis dan infiltrat sel inflamasi limfosit pada perivaskular di superfisial dermis.

Pada ACH tidak didapatkan abnormalitas sistemik, dan uji laboratorium umumnya dalam batas normal. Pustul yang terbentuk adalah steril. Pada kasus lanjut, gambaran radiologis dapat menunjukkan atrofi falangs distal dan artropati sendi interfalangeal. ${ }^{2}$ Pada kasus ini tidak terdapat kelainan sistemik dan pemeriksaan laboratorium dalam batas normal. Pewarnaan Gram dan kultur pus adalah steril dan gambaran radiologis menunjukkan osteoporosis.

Pada evaluasi awal, penyakit kulit dengan gambaran serupa harus dipertimbangkan, misalnya pompholyx, dermatitis kontak, paronikia bakterial atau fungal. ${ }^{3}$ Penting untuk mempertimbangkan sejumlah kondisi tersebut dan mengeksklusi sebelum sampai pada diagnosis kuat $\mathrm{ACH}^{4}$

Pengobatan ACH sulit karena kondisi ini resisten terhadap terapi dan tidak terdapat obat yang dapat menghasilkan remisi yang bertahan lama. Karena kelangkaan penyakit, studi yang telah dipublikasi terbatas pada laporan kasus saja, sehingga tidak ada pedoman manajemen terapeutik yang jelas. ${ }^{1,4}$ Pada prinsipnya, rejimen yang digunakan untuk pengobatan PPP juga dapat digunakan untuk terapi ACH. Hasil terapeutik bertahan selama obat diberikan, dan relaps terjadi setelah dosis diturunkan atau obat dihentikan. ${ }^{2,7}$

Obat topikal misalnya kortikosteroid, tar, ditranol, krim tretinoin, inhibitor kalsineurin, analog vitamin D3 dan beberapa antimetabolit termasuk krim fluorourasil 5\% dan mechlorethamine, telah digunakan dengan berbagai hasil pada sejumlah kasus yang terbatas, namun rangkaian evaluasi besar dan durasi pengobatan tersebut masih belum memadai. ${ }^{1,4,10}$ Steroid topikal poten atau superpoten, biasanya dengan cara oklusif, berguna untuk mencegah pustulasi, ${ }^{2}$ dengan mekanisme kerja sebagai anti ${ }^{1}$ inflamasi, anti ${ }^{1}$ proliferatif, imunosupresif, dan vasokonstriksi. Kortikosteroid telah menjadi terapi topikal primer dalam manajemen $\mathrm{ACH}$, baik secara tunggal atau kombinasi dengan obat sistemik lain. Pada kasus ini, pasien diberikan salep klobetasol propionate 0,05\% yang dioklusi dua kali sehari. Sebulan setelah terapi tidak tampak tanda perbaikan. Pustul dan krusta tetap terbentuk, dan kulit di sekitar kuku masih eritematosa. Oleh karena tidak tampak perbaikan, maka dipertimbangkan kombinasi dengan regimen sistemik.

Regimen sistemik, misalnya kortikosteroid oral, metotreksat, retinoid, siklosporin, tetrasiklin, dapson, dan kolkisin telah diujikan dan dilaporkan berhasil pada beberapa kasus. Namun hasil yang berbeda didapatkan pada laporan lainnya. Selain itu, efek samping sistemik sering tidak mendukung pengobatan dan rekurensi cepat selalu terjadi ketika dosis diturunkan. Temuan terbaru, yaitu agen biologi, termasuk anti $\mathrm{TNF} \alpha$, telah menambahkan dimensi baru terhadap manajemen ACH. Efalizumab, infliximab, adalimumab, dan etanersep dilaporkan berhasil mengobati ACH yang persisten. ${ }^{11-13}$ Dapson, dengan kemampuan antiinflamasi yang sangat baik di samping sifat antibakterialnya, adalah yang pertama dan yang paling banyak digunakan dalam mengobati pasien dengan dermatitis herpetiformis sejak awal 1950an, dan digunakan pada banyak uji terapeutik pada saat ini dalam berbagai penyakit. Pada dermatosis di mana terapi dapson dilaporkan efektif memiliki ciri yang sama, yaitu granulosit sebagai sel utama pada infiltrat. Oleh karena itu terapi dapson dapat dipertimbangkan pada lesi patologis yang ditandai oleh infiltrat neutrofilik yang abnormal dan dikaitkan dengan agen infeksius. Berdasarkan pertimbangan keterlibatan prominen neutrofilik pada ACH, dapson merupakan pilihan terapeutik yang masuk akal. Yang dkk. (2003). melaporkan satu kasus ACH pada pria 66 tahun yang gagal diterapi dengan kortikosteroid topikal dan emolien politar namun memberi respons cepat terhadap terapi dapson. ${ }^{1,14}$

Saat ini banyak studi berusaha menentukan bagaimana mekanisme dapson memberikan efek antiinflamasi. Studi in vitro menunjukkan bahwa dapson menghambat kemotaksis neutrofilik manusia melalui sistem transduksi sinyal protein $\mathrm{G}$ dan mengganggu migrasi kemotaktik neutrofil melalui supresi fungsi adhesi ke epidermis yang diperantarai integrin. Supresi perekrutan 
neutrofil berperan pada berkurangnya influks neutrofil ke dermis pada pasien yang diobati. Dapson juga terbukti mampu menghambat sistem sitotoksik myeloperoxidaseH2O2-halide neutrofil dan ledakan neutrofil respiratorik manusia yang diperantarai zimosan. Hal tersebut menyebabkan efek supresif dapson terhadap enzim sitotoksik pada lokasi lesi. Melalui mekanisme di atas, dapson berhasil mensupresi infiltrasi neutrofil yang abnormal dan melindungi jaringan dari cedera yang diperantarai neutrofil, serupa pada ACH. ${ }^{1,14}$

\section{DAFTAR PUSTAKA}

1. Yang HH, Chen HC, Chen HC, Wu YH, Su HY. Acrodermatitis continua of Hallopeau. Dermatol Sinica. 2003;21:16570

2. Mrowietz U. Pustular Eruptions of Palms and Soles. Dalam: Goldsmith LA, Katz SI, Gilchrest BA, Paller AS, Leffel DJ, Wolff K, penyunting. Fitzpatrick's Dermatology in General Medicine. Edisi ke-8. New York: McGraw-Hill; 2012.h.256-8

3. Boltan LE, Menter A. Pustules and dystrophy of the nails. Bayl Univ Med Cent. 2009; 22(2):162-3

4. Sehgal VN, Verma P, Sharma S, Srivastava G, Aggarwal AK, Rasool F, dkk. Acrodermatitis continua of Hallopeau: evolution of treatment options. Int J Dermatol. 2011. 50:1195-211.

5. Ranugha PS, Kumari R, Thappa DM. Acrodermatitis continua of hallopeau evolving into generalised pustular psoriasis. Indian J Dermatol. 2013; 58:161

6. Casals J, Mello A, Coleto C, Takahashi M, Nico M.. Using oral tetracycline and topical betamethasone valerate to treat acrodermatitis continua of Hallopeau. Cutis. 2002;70:106-8

7. Mengesha YM and Bennett ML. Pustular skin disorders. Am J Clin Dermatol. 2002;3:389-400
Sebelum terapi dengan dapson, evaluasi klinis yang cermat termasuk riwayat pengobatan, pemeriksaan darah lengkap, dan fungsi hepar harus dilakukan untuk mencegah efek samping yang mungkin disebabkan oleh dapson; di antaranya adalah hemolisis, methemoglobinemia, dan agranulositosis. ${ }^{1,14}$ Setelah pemeriksaan laboratorium dan hasilnya normal, maka dapat diberikan dapson 50 $\mathrm{mg} /$ hari. Hasil pengobatan dapson memuaskan. Obat ini memperbaiki akropustulosis dalam 4 minggu (gambar 6), meskipun terdapat efek samping yaitu anemia.

8. Waller JM, Wu JJ, Murase JE, Dyson SW and Kelly KM. Chronically painful right thumb with pustules and onycholysis. Clin Exper Dermatol 2007;32:619-20

9. Razera F, Olm GS, Bonamigo RR. Neutrophilic dermatoses - Part II. An Bras Dermatol 2011; 86:195-211

10. Berker D. Management of psoriatic nail disease. Semin $\mathrm{Cu}-$ tan Med Surg 2009;28:39-43

11. Archa SN, Wongpraparut C. A Recalcitrant acrodermatitis continua of Hallopeau successfully treated with etanercept. J Med Assoc Thai 2011;94:1154-7

12. Lefkir S, Slimani S, Brahimi N, Rezig AL. Successful treatment of Acrodermatitis continua of Hallopeau associated with psoriatic arthritis with Adalimumab. Eur J Rheumatol 2015;2:78-9

13. Sopkovich JA, Poulos GA, Wong HK. Acrodermatitis continua of Hallopeau successfully treated with Adalimumab. J Clin Aesthet Dermatol 2012;5:60-2

14. Wozel G, Blasum C. Dapsone in dermatology and beyond. Arch Dermatol Res 2014;306:103-24 